UDC 378.147:78

DOI https://doi.org/10.31470/2415-3729-2021-13-232-245

\title{
Methodological Bases for the Formation of Professional Competence of Future art Specialties Teachers
}

\section{Liudmyla Romanyshyna}

Doctor of Sciences in Pedagogy, Professor,

Head of the Pedagogy Department,

Khmelnytsky Humanitarian and Pedagogical Academy,

$\triangle 139$, Proskurivskoho Pidpillia Str., Khmelnytskyi, Ukraine, 29013

E-mail: romanyshyna43@ukr.net

ORCID: http://orcid.org/0000-0002-6026-2614

\section{Oleksandr Polishchuk}

Doctor of Sciences in Philosophy, Professor,

Vice-rector for Scientific and Pedagogical Work,

Khmelnytskyi Humanitarian and Pedagogical Academy

$\triangle 139$, Proskurivskoho Pidpillia Str., Khmelnytskyi, Ukraine, 29013

E-mail: Prokurator2007@ukr.net

ORSID http://orcid.org/0000-0002-9838-7105

Date of receipt of the article: April 18, 2021 Article accepted for publication: June 02, 2021

\section{Методологічні основи формування професійної компетентності майбутніх учителів мистецьких спеціальностей}

\section{Людмила Михайлівна Романишина}

доктор педагогічних наук, професор, завідувач кафедри педагогіки, Хмельницька гуманітарно-педагогічна академія,

$\triangle$ вул. Проскурівського підпілля, 139, м. Хмельницький, Україна, 29013

\section{Олександр Сергійович Поліщук}

доктор філософських наук, професор, проректор,

Хмельницька гуманітарно-педагогічна академія

$\triangle$ вул. Проскурівського підпілля, 139, м. Хмельницький, Україна, 29013

Дата надходження статті: 18 квітня 2021 p.

Стаття прийнята до друку: 02 червня 2021 р.

\section{Abstract}

The article is devoted to the theoretical analysis of methodological bases for the formation of professional competence of applicants of 
higher art and pedagogical education. The purpose of the article is to substantiate the leading methodological approaches to the formation of professional competence of future teachers of art specialties. Methods. The following methods were used in the research process: analysis of scientific and pedagogical literature, generalization, synthesis, formulation of conclusions. The results. The authors of the article highlight the essence of the concept of «professional competence of future teachers of art specialties» and outline the directions of formation of this pedagogical category. The article suggests the analysis of the concept of «methodology» and «methodological approach». The benefit of the study is that the authors proved that the successful formation of professional competence of future teachers of art specialties will contribute to the implementation in the educational process of higher pedagogical education ideas of competency, system, activity, culturological, axiological and acmeological approaches. The essence and content of the mentioned methodological approaches in the context of art pedagogy are characterized. Conclusions. The authors of the article state that the analysis of scientific literature together with the essence and specifics of forming the professional competence of future teachers of art specialties enabled definition and theoretical substantiation of the leading methodological approaches, which realization in educational process of establishments of higher pedagogical education will promote achievement of the stated purpose. Among the outlined methodological approaches, the authors define the most important as studies have shown, they are acmeological, culturological and competence approaches. The competence approach helped to increase the professional competence of future teachers of art history. The acmeological approach allowed us to outline new plans and tasks, more complex than the previous ones. The culturological approach allowed outlining the main tasks of professional training of future teachers of art history. Their use should be done due to a number of factors defined by the authors according to every approach.

Key words: professional competence, future teachers of art specialties, formation of professional competence of future teachers of art specialties, methodology, methodological approach, pedagogical principle.

\section{References}

1. Anishchenko, V. \& Padalka, O. (2013). Kulturolohichnyi pidkhid $\mathrm{u}$ profesiinii pidhotovtsi vchytelia [Culturological approach in teacher 
training]. Osvita doroslykh: teoriia, dosvid, perspektyvy-Adult education: theory, experience, prospects, 6, 103-107 [in Ukrainian].

2. Busel, V. T. (Ed.) (2004). Velykyi tlumachnyi slovnyk suchasnoi ukrainskoi movy [Large explanatory dictionary of the modern Ukrainian language]. Kyiv; Irpin: VTF «Perun» [in Ukrainian].

3. Honcharenko, S. (1997). Ukrainskyi pedahohichnyi slovnyk [Ukrainian pedagogical dictionary]. Kyiv: Lybid [in Ukrainian].

4. Krasovska, O. (2017). Teoretychni ta metodychni zasady profesiinoi pidhotovky maibutnikh uchyteliv pochatkovoi shkoly u haluzi mystetskoi osvity zasobamy innovatsiinykh tekhnolohii [Theoretical and methodical principles of professional preparation of future teachers of initial school in industry of artistic education by facilities of innovative technologies.]. Doctor of Pedagogic Sciences Thesis. Zhytomyr [in Ukrainian].

5. Masol, L. (2010). Estetyzatsiia navchalno-vykhovnoho protsesu $\mathrm{v}$ zahalnoosvitnii shkoli [Aestheticization of the educational process in secondary school]. Teoretyko-metodychni problemy vykhovannia ditei ta uchnivskoi molodi - Theoretical and methodological problems of raising children and students, 14, 240-251 [in Ukrainian].

6. Masol, L. (2004). Kontseptsiia khudozhno-estetychnoho vykhovannia uchniv u zahalnoosvitnikh navchalnykh zakladakh [The concept of artistic and aesthetic education of students in secondary schools]. Informatsiinyi zbirnyk MON Ukrainy - Information collection of the Ministry of Education and Science of Ukraine, 9, 7-23 [in Ukrainian].

7. Onyshchenko, N.(2021). Metodolohichnipidkhody do vykladannia pedahohichnykh dystsyplin u protsesi profesiinoi pidhotovky maibutnikh uchyteliv [Methodological approaches to teaching pedagogical disciplines in the process of professional training of future teachers]. Retrieved from http://pedagogy-journal.kpu.zp.ua/archive/2021/75/part_2/31.pdf [in Ukrainian].

8. Selevko, G. (2006). Entsiklopediya obrazovatelnyih tehnologiy: v 2 t., [Encyclopedia of educational technologies: in 2 volumes]. Moskva: NII shkolnyih tehnologiy. Vol. 1 [in Russian].

9. Sotska, H. Akmeolohichnyi pidkhid u pedahohichnii osviti Ukrainy [Acmeological approach in pedagogical education of Ukraine]. Edukacja dla przyszłości w świetle wyzwań XXI wieku, 1, 387-397 [in Ukrainian]. 
10. Chaika, V. (2011). Osnovy dydaktyky: navchalnyi posibnyk [Fundamentals of didactics: a textbook.]. Kyiv: Akademvydav [in Ukrainian].

11. Shabanova, Yu. (2014). Systemnyi pidkhid u vyshchii shkoli: pidruchnyk [System approach in high school: a textbook]. Dnipropetrovsk: NHU [in Ukrainian].

12. Shcholokova, O. (2007). Modernizatsiia fakhovoi mystetskoi osvity u konteksti suchasnykh humanistychnykh idei [Modernization of professional art education in the context of modern humanistic ideas.]. Naukovyi chasopys NPU im. M. P. Drahomanova-Scientific journal of NPU named after M. P Dragomanova, 4 (9), 11-14 [in Ukrainian].

\section{Вступ}

У сучасних умовах культурного відродження українського суспільства, його переорієнтації на національні та духовні цінності зростає потреба удосконалення процесу професійної підготовки майбутніх учителів мистецьких спеціальностей, які реалізують мистецьку освіту підростаючого покоління. Сьогодні мистецькій галузі потрібні фахівці із високим рівнем професійної компетентності, інноваційним стилем педагогічного мислення, здатністю адаптуватися до змін у соціумі, потребою у творчому самоствердженні та постійному саморозвитку; здатних розвивати в учнів здатність до сприймання, розуміння й творення художніх образів, інтересу та ціннісного ставлення до мистецтва; створювати умови для творчої реалізації школярів, формувати у них художньо-естетичні компетентності тощо [6].

За таких умов, одним із актуальних напрямків наукових досліджень у сфері мистецької педагогіки $є$ пошук нових, ефективніших шляхів формування професійної компетентності майбутніх учителів мистецьких спеціальностей, та, зокрема, розроблення ефективного теоретико-методологічного підгрунтя означеного процесу.

До проблеми формування професійної компетентності майбутніх учителів мистецьких спеціальностей звертається чимало дослідників, серед яких: Л. Гаврілова, А. Козир, Л. Масол, М. Мороз, О. Олексюк, Г. Падалка, О. Щолокова та інші. Дослідники В. Аніщенко, О. Красовська, Н. Онищенко, О. Па- 
далка, Г. Сотська, Ю. Шабанова аналізують методологічні засади фахової підготовки здобувачів вищої педагогічної освіти.

Водночас зазначимо, що враховуючи висвітлені нами чинники модернізації вітчизняної парадигми освіти, більш глибокого наукового осмислення потребують методологічні основи професійної підготовки здобувачів вищої мистецько-педагогічної освіти. Тому метою статті визначили обгрунтування провідних методологічних підходів до формування професійної компетентності майбутніх учителів мистецьких спеціальностей.

\section{Матеріал і методи досліджень}

У процесі дослідження було використано такі методи: аналіз науково-педагогічної літератури, узагальнення, синтез, формулювання висновків.

\section{Результати та їх обговорення}

У сучасних науково-педагогічних дослідженнях професійна компетентність майбутніх учителів мистецьких спеціальностей розглядається як поєднання психолого-педагогічних та мистецтвознавчих знань, умінь та навичок, творчого використання цінного досвіду, теоретико-прикладної готовності до його використання [5, c. 53]. Відтак, формування цього педагогічного явища передбачає розвиток у здобувачів вищої освіти ерудиції в галузі художньої культури, педагогіки, психології, мистецтвознавства, естетики; оволодіння студентською молоддю практичними уміннями й навичками (педагогічними, психологічними, хормейстерськими, інструментально-виконавськими, хореографічними, художніми, акторськими); розвиток особистісних якостей та здібностей, необхідних для успішного здійснення основних функцій учителя мистецьких дисциплін - педагогічних (толерантність, комунікативність, організаторсько-конструктивні здібності, зосередженість, тактовність, витримка, здатність до емпатії, ідентифікації) та фахових [5].

Основою реалізації означеного процесу у закладах вищої педагогічної освіти є методологічні підходи та принципи, які обумовлюють методи, форми, засоби, способи досягнення поставленої мети.

Вважаємо за необхідне осмислити поняття «методологія» та «методологічний підхід». 
У сучасних науково-педагогічних дослідженнях методологією називають специфічну діяльнісну систему, яка поєднує конкретні принципи, категорії, теорії, парадигми, методи, а також є способом організації науково-дослідної діяльності [7, с. 154]. Вона утворює основу наукового пізнання, відображену у комплексі методологічних підходів, реалізація яких уможливлює здійснення цілісного вивчення об'єктів пізнання.

3 погляду С. Гончаренка, методологічний підхід є, 3 одного боку, певним вихідним принципом, початковою позицією, основним положенням чи переконанням (цілісний, комплексний, системний, синергетичний та інші), а 3 іншого - напрямом аналізу предмета дослідження (історичний, логічний, змістовий, формальний тощо) [3, с. 105]. На думку Г. Селевка, у контексті педагогічної науки означена категорія містить базові поняття, що використовуються у процесі навчання; принципи як вихідні положення здійснення навчально-виховної діяльності, що впливають на вибір змісту, форм і способів організації освітнього процесу, а також методів та прийомів його побудови [8, с. 71].

Ми переконані, що ефективність процесу формування професійної компетентності майбутніх учителів мистецьких спеціальностей обумовлює застосування таких взаємопов'язаних методологічних підходів, а саме: компетентнісного, системного, діяльнісного, культурологічного, аксіологічного та акмеологічного. Розглянемо їх детальніше.

Ключовим методологічним інструментом формування професійної компетентності майбутніх учителів мистецьких спеціальностей $є$ компетентнісний підхід, реалізація якого освітньому процесі закладів вищої освіти «детермінує модернізацію усіх компонентів педагогічної моделі (мета, зміст, технології, оцінювання результатів навчання, учіння і виховання, самовиховання), переносить акценти із засвоєння художньої інформації на формування комплексу компетентностей» [4, с. 117], а також здатності до їх практичного і творчого застосування у різних ситуаціях. Такий підхід, на думку В. Чайки, сприяє усвідомленню студентською молоддю мотивів власної діяльності, прагнень і ціннісних орієнтацій, уявлень про свої соціально-професійні ролі; обумовлює самоаналіз й оцінку власного рівня розвитку особистісних якостей, знань, умінь, 
навичок та передбачає регулювання на цій основі свого саморозвитку, власної діяльності [10].

Методологічною основою компетентнісного підходу, як зазначає Н. Онищенко, є принципи діагностичності (орієнтація на досягнення діагностованого результату, що проявляється у мисленні, поведінці особистості), комплексності (здатність до вирішення сукупності завдань), міждисциплінарності (врахування як освітніх, так і зовнішніх середовищних факторів i впливів) та практичної спрямованості (зв'язку теорії з практикою) [7, с. 155].

Застосування компетентнісного підходу у процесі професійної підготовки майбутніх учителів мистецьких спеціальностей сприятиме формуванню у них системи компетентностей та професійної компетентності в цілому, що забезпечить готовність випускників ЗВО до здійснення мистецько-освітньої діяльності, подальшого особистісного та професійного розвитку, активної участі в соціумі.

Системний підхід є способом наукового пізнання, напрямком методології досліджень, який полягає в аналізі об'єкта дослідження як цілісної множини елементів у сукупності відношень і зв' язків між ними, тобто кваліфікує об'єкт як систему - сукупність елементів, що перебувають у відношеннях і зв'язках один з одним та утворюють певну цілісність, єдність [11, с. 14]. У змісті такого підходу, на думку Ю. Шабанової, поєднуються принципи цілісності (розглядає систему як єдине ціле і неподільне та підсистему для вищих рівнів), ієрархічності будови (підпорядкованість нижчих елементів вищим), структуризації (аналіз компонентів системи та їхніх взаємозв'язків у межах певної організаційної структури), множинності (використання моделей різних рівнів для опису окремих елементів і системи в цілому) та системності (властивість об'єкта володіти усіма ознаками системи) [11, с. 32].

Реалізація системного підходу дозволяє розглядати вищу мистецьку освіту як цілісну педагогічну систему в структурному, функціональному й генетичному аспектах, базовим елементом якої стає іiі мета - виховання та розвиток творчої особистості майбутнього учителя мистецьких спеціальностей, яка відповідає перманентним вимогам суспільства й указує на особистісні та професійні якості фахівця, які потрібні на сучасному етапі розвитку України [4, c. 103]. 
На необхідності використання ідей системного підходу у процесі формування професійної компетентності майбутніх учителів мистецьких спеціальностей наголошує О. Щолокова. 3 погляду вченої, такий підхід відіграє важливу роль у вивченні різноманітних мистецькопедагогічних явищ, сприяє озброєнню здобувачів вищої освіти не лише фактичними теоретичними знаннями, а й методологічними, які дають основну інформацію про важливі елементи знань та їхні структурні зв'язки [12, с. 13]

Очевидно, що формування професійної компетентності майбутніх учителів мистецьких спеціальностей здійснюється у різних видах діяльності. За таких умов, одним із провідних методологічних підходів у контексті нашого дослідження визначаємо діяльнісний, який передбачає розуміння професійної підготовки студентської молоді як процесу діяльності, забезпечує їхнє особистісне та професійне становлення. Діяльнісний підхід спрямований на формування пізнавальної активності майбутніх учителів мистецьких спеціальностей, самостійності, готовності до самоосвіти; передбачає залучення здобувачів вищої освіти у різноманітні професійнопедагогічні відносини за допомогою засвоєння системи компетентностей; визначає організацію професійної підготовки майбутніх педагогів на основі моделі мистецько-освітньої діяльності.

Відмітимо, що сьогодні мистецько-освітня діяльність учителя у вузькому розумінні передбачає трансляцію підростаючому поколінні системи мистецьких компетентностей та спрямована на розвиток художньо-творчих здібностей та культурну соціалізацію молоді у суспільстві; у широкому значенні така діяльність розглядається як різновид соціальної діяльності, яка має на меті трансляцію накопиченого людством ціннісного досвіду духовної і матеріальної художньої культури від старших поколінь до молодших [4, с. 115].

Отже, ключовою метою реалізації діяльнісного підходу в освітньому процесі закладів вищої педагогічної освіти $€$ формування у майбутніх учителів мистецьких спеціальностей готовності до професійної діяльності через динамічну взаємодію суб'єктів педагогічного процесу в умовах спеціально створеного освітнього середовища, тобто через навчання у діяльності.

На нашу думку, успішному формуванню професійної компетентності майбутніх учителів мистецьких спеціальностей 
сприяє використання ідей культурологічного підходу, який у сучасних науково-педагогічних дослідженнях тлумачиться як «сукупність теоретико-методологічних положень й організаційно-педагогічних заходів, спрямованих на забезпечення умов для оволодіння майбутніми учителями змістом культури й розвитку педагога як іiі суб'єкта» [1, с. 105]; він передбачає тісний зв'язок навчання із культурним надбанням людства.

Необхідність реалізації культурологічного підходу у професійній підготовці майбутніх учителів мистецьких спеціальностей пояснюється тим, що, по-перше, студентська молодь повинна досягнути високого рівня загальної культури, ключовими складовими якої (враховуючи специфіку мистецько-освітньої діяльності) є педагогічна (високий рівень особистісного розвитку вчителя, педагогічна техніка, ерудиція тощо) та мистецька культура (система знань, умінь, навичок, оцінок, переконань, здібностей, смаків, мотивів, які обумовлюють здатність сприймати, адекватно оцінювати та інтерпретувати твори мистецтва). Така культура формується у процесі активної навчальної, педагогічної та художньої діяльності. По-друге, учитель мистецьких спеціальностей має володіти здатністю до трансляції підростаючому поколінню культурних надбань людства, що є одним із ключових завдань мистецької освіти школярів.

Погоджуємося з О. Красовською, що мистецьку освіту в контексті культурологічного підходу можна розглядати як «продукт культури, результат культурно-історичного розвитку людства, а вчителів і здобувачів освіти - не лише як пасивних споживачів, а й творців культури в їі безмежному просторі» [4, с. 97].

Отже, втілення культурологічного підходу у процесі формування професійної компетентності майбутніх учителів мистецьких дисциплін сприятиме досягненню освітніх цілей; розширенню загального світогляду здобувачів вищої освіти, розвитку у них високого рівня загальної, педагогічної, мистецької культури; забезпечить здатність студентської молоді до ефективного здійснення музичноосвітньої діяльності на культурологічних засадах; сприятиме успішній реалізації мистецької освіти школярів.

Тісно із культурологічним підходом пов'язаний аксіологічний nidxid, реалізація якого в освітньому процесі закладів вищої педагогічної освіти сприятиме формуванню у студентської молоді 
системи мистецьких знань, інтерпретаційних умінь і навичок, мистецької рефлексії, що є необхідними для роботи з художніми творами, аналізу їх змісту, ідей та засобів мистецької виразності [12].

Аналізуючи необхідність використання аксіологічного підходу у вищій мистецько-педагогічній освіті, О. Красовська наголошує на необхідності формування у студентської молоді аксіологічного ставлення до мистецтва, оскільки сьогодні головним механізмом виховання підростаючого покоління є зміст освіти. На думку вченої, стрижнем та рушійною силою розвитку такого ставлення є ціннісні орієнтації - феномени, які спрямовують навчальну та художню роботу здобувачів вищої освіти. Визначальними у структурі професійної компетентності майбутніх учителів мистецьких спеціальностей дослідниця називає мистецькі, педагогічні, загальнолюдські та національні цінності [4, с. 99 101].

Важливу роль у формуванні професійної компетентності майбутніх учителів мистецьких спеціальностей відіграє застосування ідей та методологічних принципів акмеологічного підходу. Базовим поняттям такого підходу є термін «акме» - «соматичний, фізіологічний, психічний і соціальний стан особистості, що характеризується зрілістю їі розвитку, досягнення найвищих показників у іiі діяльності та творчості» [2, с. 17]. Таким чином, акме є багатомірною характеристикою стану людини, яка охоплює певний період іiі прогресивного становлення і пов'язана 3 досягненнями найвищих результатів у фахово-особистісному розвитку, професій діяльності, творчості.

Акмеологічний підхід спрямований на забезпечення постійного самовдосконалення майбутніх учителів мистецьких спеціальностей, яке передбачає рефлексію, ініціативність, передбачливість, прагнення до самореалізації та творчості, інтеграцію власного професійного шляху тощо [9, с. 389]; є орієнтиром фахового становлення здобувачів вищої мистецько-педагогічної освіти.

Погоджуємося із Г. Сотською [9], що основним засобом формування професійної компетентності майбутніх учителів мистецьких спеціальностей на засадах акмеологічного підходу є акмеологічні технології, серед яких: модульно-тьюторська, кооперованого навчання, проблемно-пошукова, особистісного зростання, життєвого проєктування і саморозвитку тощо. Ключовим методом означених технологій є акмеологічний вплив на особистість фахівця. 


\section{Висновки}

Отже, аналіз наукової літератури, сутності та специфіки формування професійної компетентності майбутніх учителів мистецьких спеціальностей уможливив визначення й теоретичне обгрунтування провідних методологічних підходів, реалізація яких в освітньому процесі закладів вищої педагогічної освіти сприятиме досягненню поставленої мети. До таких підходів ми віднесли компетентнісний, системний, діяльнісний, культурологічний, аксіологічний та акмеологічний. Їх використання зумовлюється низкою чинників, серед яких виділили ключові: компетентнісний - необхідністю формування у студентської молоді професійних компетентностей та здатності до їх реалізації у мистецько-освітній діяльності; системний - потребою осмислення структури процесу фахової підготовки здобувачів вищої освіти, сутності та змісту професійної компетентності майбутніх учителів мистецьких спеціальностей; діяльнісний - у професійному розвитку студентської молоді засобами різних видів діяльності (навчальної, професійної), формуванні здатності здобувачів вищої педагогічної освіти до здійснення мистецько-освітньої діяльності; культурологічний - у досягненні майбутніми учителями мистецьких спеціальностей високого рівня загальної, педагогічної та мистецької культури; аксіологічний - потребою у формуванні ціннісних орієнтацій здобувачів вищої мистецько-педагогічної освіти; акмеологічний - забезпечення професійного розвитку майбутніх учителів мистецьких спеціальностей, активізації у них прагнення до самовдосконалення та творчої діяльності.

Перспективним напрямком подальших досліджень у контексті порушеної теми $є$ модернізація моделі формування професійної компетентності майбутніх учителів мистецьких спеціальностей на засадах окреслених методологічних підходів.

\section{Література}

1. Аніщенко В., Падалка О. Культурологічний підхід у професійній підготовці вчителя. Освіта дорослих: теорія, досвід, перспективи. 2013. Вип. № 6. С. 103-107.

2. Великий тлумачний словник сучасної української мови / уклад. В. Т. Бусел. К., Ірпінь: ВТФ «Перун», 2004. 1440 с.

3. Гончаренко С. Український педагогічний словник. Київ: Либідь, 1997. 373 с. 
4. Красовська О. Теоретичні та методичні засади професійної підготовки майбутніх учителів початкової школи у галузі мистецької освіти засобами інноваційних технологій: дис. ... докт. пед. наук: 13.00.04. Житомир, 2017. 567 с.

5. Масол Л. Естетизація навчально-виховного процесу в загальноосвітній школі. Теоретико-методичні проблеми виховання дітей та учнівської молоді. Кіровоград, 2010. Вип. № 14, кн. I С. 240251.

6. Масол Л. Концепція художньо-естетичного виховання учнів у загальноосвітніх навчальних закладах. Інформаційний збірник $М O H$ України. 2004. Вип. № 9. С. 7-23.

7. Онищенко Н. П. Методологічні підходи до викладання педагогічних дисциплін у процесі професійної підготовки майбутніх учителів. URL: http://pedagogy-journal.kpu.zp.ua/archive/2021/75/ part_2/31.pdf (дата звернення: 20.08.2021 р.).

8. Селевко Г. К. Энциклопедия образовательных технологий: в 2 т. Москва: НИИ школьных технологий, 2006. Т. 1. 816 с.

9. Сотська Г. Акмеологічний підхід у педагогічній освіті України. Edukacja dla przyszłości w świetle wyzwań XXI wieku. T. 1. С. 387-397.

10. Чайка В. М. Основи дидактики: навчальний посібник. Київ: Академвидав, 2011. 238 с.

11. Шабанова Ю. Системний підхід у вищій школі: підручник Дніпропетровськ: НГУ, 2014. 120 с.

12. Щолокова О. П. Модернізація фахової мистецької освіти у контексті сучасних гуманістичних ідей. Науковий часопис НПУ ім. М. П. Драгоманова. Серія 14. Теорія і методика мистеиької освіти: зб. наук. пр. Київ: НПУ, 2007. Вип. № 4 (9). С. 11-14.

\section{Романишина Л.М., Поліщук О.С.}

\section{Методологічні основи формування професійної компетентності майбутніх учителів мистецьких спеціальностей}

\section{Анотація}

Стаття присвячена теоретичному аналізу методологічних основ формування професійної компетентності здобувачів вищої 
мистецько-педагогічної освіти. Висвітлено сутність концепту «професійна компетентність майбутніх учителів мистецьких спеціальностей». Окреслено напрями формування цієї педагогічної категорії.

Проаналізовано поняття «методологія», «методологічний підхід». Доведено, що успішному формуванню професійної компетентності майбутніх учителів мистецьких спеціальностей сприятиме реалізація в освітньому процесі закладів вищої педагогічної освіти ідей компетентнісного, системного, діяльнісного, культурологічного, аксіологічного та акмеологічного підходів. Охарактеризовано сутність та зміст означених методологічних підходів у контексті мистецької педагогіки.

Серед окреслених методологічних підходів найбільш важливе значення, як показали дослідження, мають акмеологічний, культурологічний та компетеньісний підходи. Компетентісний підхід сприяв підвищенню професійної компетентності майбутніх учителів мистецвознавсва. Акмеологічний підхід дозволяв накреслювати нові плани і завдання, більш складні ніж попередні. Культурологічний підхід дозволяв окреслити основні завдання професійної підготовки майбутніх учителів мистецтвознавства.

Ключові слова: професійна компетентність, майбутні учителі мистецьких спеціальностей, формування професійної компетентності майбутніх учителів мистецьких спеціальностей, методологія, методологічний підхід, педагогічний принцип.

\section{Романишина Л.М., Полищук А.С.}

\section{Методологические основы формирования профессиональной компетентности будущих учителей художественных специаль- ностей}

\section{Аннотация}

Статья посвящена теоретическому анализу методологических основ формирования профессиональной компетентности соискателей высшего художественно-педагогического образования. Освещено сущность концепта «профессиональная компетентность будущих 
учителей художественных специальностей». Определены направления формирования этой педагогической категории.

Проанализированы понятия «методология», «методологический подход». Доказано, что успешному формированию профессиональной компетентности будущих учителей художественных специальностей будет способствовать реализация в образовательном процессе учреждений высшего педагогического образования идей компетентностного, системного, деятельностного, культурологического, аксиологического и акмеологического подходов. Охарактеризировано сущность и содержание указанных методологических подходов в контексте художественной педагогики.

Серед окреслених методологічних підходів найбільш важливе значення, як показали дослідження, мають акмеологічний, культурологічний та компетеньісний підходи. Компетентісний підхід сприяв підвищенню професійної компетентності майбутніх учителів мистецвознавсва. Акмеологічний підхід дозволяв накреслювати нові плани і завдання, більш складні ніж попередні. Культурологічний підхід дозволяв окреслити основні завдання професійної підготовки майбутніх учителів мистецтвознавства.

Среди очерченных методологических подходов наиболее важное значение, как показали исследования, имеют акмеологический, культурологический и компетентностный подходы. Компетентностный подход способствовал повышению профессиональной компетентности будущих учителей искусствоведения. Акмеологический подход позволил наметить новые планы и задачи, более сложные чем предыдущие. Культурологический подход позволял определить основные задачи профессиональной подготовки будущих учителей искусствоведения.

Ключевые слова: профессиональная компетентность, будущие учителя художественных специальностей, формирование профессиональной компетентности будущих учителей художественных специальностей, методология, методологический подход, педагогический принцип. 